\title{
WILLI MÜNZENBERG: PROPAGANDIST FOR AND AGAINST THE COMINTERN
}

Brief notices in French newpsapers of October 22, 1940 announcing the death of Willi Münzenberg failed to attract the attention of the international press occupied with reporting the progress of the Second World War. Münzenberg's body had been discovered in the woods of Cagnet in Southwestern France with a wire garrote around the neck. The cause and macabre circumstances of death were shrouded in mystery. ${ }^{1}$ More than twenty years have blurred and obscured the career of the most exceptional propagandist of the communist movement.

On the night of the Reichstag fire, February 27, 1933, Münzenberg fled across the German border and made his way to Paris. At that juncture in his life he had already attained the reputation of a masterful organizer of communist propaganda in Germany. Münzenberg, of proletarian origins, came to radical politics at an early age, assumed leadership of the Socialist Youth International in Zurich, and became an intimate of Russian and other European leftists exiled in Switzerland during the war. As one of the first German followers of Lenin, he participated in the Spartacist uprising in Germany and, because of his leadership ability and organizational skill, became leader of the Communist Youth International. In I92 I, Lenin charged him with organizing a left-wing Russian famine relief. This enterprise led to the creation of the International Workers' Relief (IAH), which became the parent body of the publishing house, daily papers, journals, illustrated weekly, film company, book and film clubs, and proletarian theater groups which comprised his propaganda empire. ${ }^{2}$ Münzenberg's position within the German and international communist

\footnotetext{
1 For an account of Münzenberg's death, see Kurt Kersten, "Das Ende Willi Münzenbergs: ein Opfer Stalins und Ulbrichts", in: Deutsche Rundschau, LXXXIII (1957), pp. 495-99.

2 For details of Münzenberg's youth, see his fragmentary autobiography Die dritte Front (Berlin, 1930). For his activities after I92 $\mathrm{r}$, see Solidarität: Zehn Jahre Arbeiterhilfe (Berlin, I931) and the interesting secondary account by his sister-in-law Margarete BuberNeumann, Von Potsdam nach Moskau (Stuttgart, 1957).
} 
movement was unique, for he enjoyed a semi-autonomous status which made it possible for him to win the support of the noncommunist left and the uncommitted for communist causes. Münzenberg was a loyal member of the German Communist party (KPD) and supported its leadership during the party's tactical turnabouts and crises, but his discipline during the late twenties and early thirties was occasionally more apparent than real. ${ }^{1}$

Hitler's easy accession to power in I 933 was a devastating blow to the German left. The leaders of the KPD were quickly taken into custody by the Nazis, and all that remained of the once powerful party was the uncoordinated activity of isolated pockets of resistance. Münzenberg refused to believe that a party which had polled six million votes in a national election could suddenly all but disappear. He came to Paris with the conviction that he would provide the propaganda necessary for an inevitably growing opposition to National Socialism in Germany and, at the same time, organize world opinion against fascism.

During the first four years in Paris Münzenberg continued his activities on behalf of the Comintern and the KPD in exile. He created a new propaganda network of publications and organizations and cast out his denunciations of the Nazis and appeals for the suffering people across the Rhine before a growing international audience of sympathizers. With the ingenuity of a conjurer and the tirelessness of a sorcerer's apprentice he created committees, commissions, and congresses, and in the midst of such frenzied activity lost sight of developments within the Soviet Union. On a trip to Moscow at the end of ${ }_{193} 6$ Münzenberg found the atmosphere ominous after the first purge trial, and he only narrowly escaped being sucked into the maelstrom of suspicion and witch hunting. For the remainder of his life Münzenberg became increasingly alienated from the Comintern although his anti-fascist activities continued unabated. Following a year of indecision in 1937 , he created the last propaganda organization of his career but this time independent of and, ultimately, in opposition to the Comintern. Anti-fascism superseded communism as the cause to which Münzenberg devoted himself completely and unsparingly, and in the service of which he came to a mysterious and gruesome end. His awakening to the realities of Comintern politics, culminating in

1 In close association with his brother-in-law Heinz Neumann's opposition group within the leadership he attempted to prevent the toppling of the Braun-Severing government in Prussia although he had joined in official attacks on the German Social Democratic party (SPD). Babette L. Gross, "Die Volksfrontpolitik in den dreissiger Jahren: Ein Beitrag zum Verständnis der kommunistischen Taktik", in: Das Parlament, B 43/62 (Oct. 24, 1962), p. 524; Kersten, Pp. 487-88. 
the Hitler-Stalin pact, is symbolic of the tragedy of his dedicated generation.

Upon his arrival in Paris in February, 1933, Münzenberg proceeded to organize a world-wide anti-fascist campaign. To gain the widest support for his activities he followed a popular front policy which became the foundation of his propaganda organization. He concentrated his energies in molding various left-wing and liberal refugees into the Committee for the Relief of Victims of German Fascism, which quickly became the efficient popular base of his operations. ${ }^{1}$

The actual center of Münzenberg's anti-fascist activities was the publishing house Editions du Carrefour with offices in Paris. It was founded in part on money rescued from Münzenberg's Neuer Deutscher Verlag of which it was a direct descendent. ${ }^{2}$ On its house staff were Otto Katz, former business manager of the Piscator Theater in Berlin, Kurt Kersten, former features editor of the Welt am Abend, and the publicists Gustav Regler and Alfred Kantorowitz. Between 1933 and 1936 Editions du Carrefour published about one hundred books and many more pamphlets. ${ }^{3}$ The purpose of these publications, which were smuggled into Germany and also translated into many languages, was to unmask Hitler and the Nazi regime before the world.

Editions du Carrefour controlled a number of periodicals the most prominent of which was the Arbeiter-Illustrierte-Zeitung. The AIZ, as it was popularly called, was a picture weekly published in Prague which combined anti-fascist material, contrasted by positive features of Soviet life, with worker-oriented informative articles about technology, sports, and nature. ${ }^{4}$ The large staff of contributors included:

1 At the same time he issued personal appeals for an international protest against the maltreatment of the thousands in concentration camps. " 30 bis 35 Konzentrationslager in Deutschland mit über 30,000 Gefangenen", in: Unsere Zeit, VI (Apr. 15, 1933), p. 59. 2 The Neuer Deutscher Verlag was the parent body of Münzenberg's propaganda empire before I 933 . It published books ranging from politics to literature, sponsored the book club Universum-Bücherei, and controlled influential newspapers and periodicals.

3 Among the books published were: Bert Brecht and Hanns Eisler, Lieder und Balladen; E. E. Kisch, Eintritt Verboten; Gustav Regler, Der Kampf um die Saar; F.C. Weiskopf, Der Marsch auf Berlin; Henri Barbusse, Stalin; Arthur Koestler, Menschenopfer unerhört; and Nazi-Führer sehen dich an. Carrefour also sponsored the Free German Library directed by a committee consisting of Heinrich Mann, Lion Feuchtwanger, Leopold Schwarzschild, E. J.Gumbel, Rudolf Breitscheid, Rudolf Olden, Emil Ludwig, and Ernst Toller. See Deutsche Freiheitsbibliothek, Eine Aufgabe (Basel, 1936).

4 The AIZ had been Münzenberg's most successful publishing venture before I 933 with a circulation of nearly half a million. In 1936 the AIZ changed its name to Die VolksIllustrierte. 
Heinrich Mann, Thomas Mann, Romain Rolland, Annold Zweig, Louis Fischer, André Malraux, Ernst Bloch, B. Traven, Léon Jouhaux, Ilya Ehrenburg, and Marcel Cachin. Other periodicals included Unsere $Z$ eit, the bi-weekly theoretical organ of the IAH; Der Gegen-Angriff, intended as a counter-irritant to Goebbels' Angriff; Weltfront gegen imperialistischen Krieg und Faschismus and Einheit, two anti-imperialist and anti-fascist journals; and Freie Jugend, aimed at German youth. ${ }^{1}$

The most sensational publication of Carrefour was Das Braunbuch über Reichstagbrand und Hitler-Terror. It attempted to demonstrate that the four accused communists, Dimitrov, Popov, Tanev, and Torgler, were innocent and that the fire had been set at the behest of Göring and Goebbels who needed scapegoats to consolidate Nazi power. It also delved into the psychological instability of Van der Lubbe, challenged the technical evidence of the fire, and exposed the Nazis' destruction of the trade unions, attacks on German culture, persecution of the Jews, and torture of prisoners. The Braunbuch was prepared by an editorial staff under Münzenberg's direction and made use of the techniques Münzenberg had found so successful in Germany before 1933: a combination of factual reports, documents, anti-Nazi interpretations, and appeals by famous personalities. The foreword was by Lord Marley, chairman of the Committee for the Relief of Victims of German Fascism, and the appended protests were by Sherwood Anderson, André Gide, Lincoln Steffens, Martin Andersen-Nexö, Henri Barbusse, Michael Gold, Egon Kisch, and Ernst Toller. From the day of its publication the book was a sensation and within several years more than half a million copies were in circulation. ${ }^{2}$

The Braunbuch had an immediate and profound effect on develop-

1 Contributors to Der Gegen-Angriff included: Toller, Johannes R. Becher, Kisch, Weiskopf, Oskar Maria Graf, Rudolf Leonhard, Michael Gold, Karl Franz, and Heinrich Kurella. Contributors to Weltfront included: Agnes Smedley, Martin Andersen-Nexö, Heintich Mann, and Willi Bredel. Contributors to Einheit included: Henti Barbusse, Tom Mooney, Toller, Kisch, and Weinert. Münzenberg was concerned particularly about the fate of German youth. In a letter to his old friend Fritz Brupbacher he wrote: "The youth is the most important part of the segments which have to be rescued from Hitler and fascism. Hitler's influence on the masses must be reversed. The periodical Freie Jugend can and must help to fulfill this burning task." Münzenberg to Brupbacher, Sept. 26, 1934, Brupbacher archive, Internationaal Instituut voor Sociale Geschiedenis, Amsterdam. I am indebted to this Institute for permission to consult materials from its Brupbacher and Paul Hertz archives.

2 By I 935, 600,000 copies of the Braunbuch had been published in twenty-three languages. Of these 15,000 had been smuggled into Germany under the innocuous covers of the Reclam edition of German classics. AIZ, XIV (Feb. 28, I935), p. 139. Arthur Koestler exaggerates in claiming that "within a few weeks, the Brown Book was translated into seventeen languages and circulated in millions of copies", Invisible Writing (New York, 1954), p. 199. Günther Nollau repeats this error verbatim in International Communism and World Revolution (New York, 196I), P. 120. 
ments in and outside Germany. ${ }^{1}$ It had been prepared to appear on the eve of the so-called counter-trial which Münzenberg had organized to undermine and discredit the Reichstag fire trial scheduled to begin in Leipzig at the end of September 1933. In April he had organized a Committee of Inquiry into the Reichstag fire composed of renowned jurists including D. N.Pritt, King's Counsel, Moro-Giafferi, former French Undersecretary of State, Georg Branting, son of the former Swedish Prime Minister, and Arthur Garfield Hays, counsel for Sacco and Vanzetti. ${ }^{2}$ The counter-trial opened at the meeting hall of the British Law Society on September 14, 1933 with the international press in full attendance. During the five days of the trial thirty experts and witnesses were called, among them the journalist Georg Bernhard, the social democrats Hertz and Breitscheid, the writers Freek van Leeuwen and Toller, and the son of Torgler and the sister of Dimitrov. ${ }^{3}$ The verdict, handed down on September 20 th and published in fifteen languages, concluded that there was no connection between the KPD and the Reichstag fire and that, in all likelihood, the fire had been set under the direction of Nazi leaders. ${ }^{4}$ On the day after this verdict the Leipzig trial began and was conducted under the shadow of Münzenberg's campaign. ${ }^{5}$ The international press reported how the Braunbuch and the London counter-trial played the role of the sixth and most important principal during the course of the trial. ${ }^{6}$ Münzenberg's propaganda had convinced the public of the innocence of the four accused communists, and the Leipzig court, under pressure of an aroused international public opinion, declared them not guilty.?

1 'The social democratic Neuer Vorwärts published an extremely favorable review of the Braunbuch praising its factual content and agreeing with its conclusions, "Göring - ein Brandstifter und Morphinist", No. Io (Aug. 20, I933), p. I. At Goebbels' direction a Baltic Nazi hack writer, Adolf Ehrt, wrote a tefutation of the Braunbuch titled Bewaffneter Aufstand of which 50,0oo copies quickly were put into circulation. See Heinz Pol, "Das Antibraunbuch", in: Die neue Weltbühne, II (Sept. 28, 1933), p. 1208.

2 The committee issued a multi-lingual bulletin, Der Reichstagbrand, of its investigation. For details of the countertrial, see Der Spruch von London (Prague, 1933), passim.

${ }^{3}$ For details of the counter-trial, see Fritz Tobias, Der Reichstagbrand: Legende und Wirklichkeit (Rastatt, I962), pp. 21 2-30. The press coverage of the counter-trial was so favorable that the German government made an unsuccessful attempt to induce the English government to halt the proceedings. Braunbuch II, p. 39 .

${ }^{4}$ Spruch von London, p. 29.

5 A pamphlet, Anklage gegen die Ankläger (Paris, 1933) was published by Carrefour and smuggled into Germany, in which leading French jurists refuted the secret indictment which the Nazi government had prepared for the trial. For details of the Leipzig trial, see Arthur Garfield Hays, City Lawyer (New York, I942), pp. 337-88.

6 Der Kampf um ein Buch (Paris, 1934), pp. 4-7.

7 The four were arrested again and detained in prison without charge. The three Bulgarians, who were Soviet citizens, wete freed after intercession of their government, but Torgler was sent to a concentration camp. 
A detailed account of the counter-trial and the Leipzig trial was published in Braunbuch II: Dimitroff contra Goering in 1934 and translated into a dozen languages. The two "brown books" were part of an anti-Nazi series of Carrefour which included the Weissbucb über die Erschiessungen des 30. Juni and Das Braune Netz. ${ }^{1}$ The first of these exposed the events surrounding the Bartholomew's night of June 30 , 1934 in which General Schleicher, Captain Ernst Röhm, and other SA leaders were assassinated; the second gave a detailed account of Hitler's propaganda and spy network outside Germany and attempted to show how this covert apparatus was preparing the way for war.

From I 933 to 1936 Münzenberg contributed articles to the various publications under his direction, ${ }^{2}$ but his energies were concentrated on organizing anti-fascist propaganda. For this purpose he created a phenomenal array of committees, conventions, leagues, and congresses. These international bodies and assemblies included the Committee Against Imperialist War and Fascism, Congress of Anti-Fascist Workers, Congress of Women Against War and Fascism, Home for Refugee Children, Free German Library, Committee for War Relief for Republican Spain, and Committee of Inquiry into Alleged Breaches of Non-Intervention Agreement in Spain. ${ }^{3}$ The nature and structure of these organizations followed a single pattern: leading non-communist intellectuals, artists, and public figures as sponsors; an international membership and body of representatives; national and local subsidiary and affiliated bodies; and a function of publicity and fund raising.

Next to the Committee for the Relief of the Victims of German Fascism, the Committee Against Imperialist War exerted the most influence and had the widest following. It had its origins in two leagues which Münzenberg had created before 1933, the League Against Imperialism and for National Independence and the League Against War and Fascism. ${ }^{4}$ One of the most spectacular meetings

1 Thirty thousand copies of Braunbuch II were smuggled into Germany under innocuous titles. The Weissbuch was published in 1934 and the Braune Netz in 1935 . These publications received highly favorable reviews in the German émigré press. See, for instance, "Standartenführer Fiedler als Weissbuch-Dementi", in: Das neue Tage-Buch, III (Jan. 5, 1935), pp. 1255-56.

2 See, for instance, "Wir müssen die Jugend gewinnen!", in: Unsere Zeit, VII (Oct., 1934); "Hilfe im Kampf gegen Hitler", in: AIZ, XIV (Dec. 5, 1935); "Helden des Frieden", Ibid., XV (April I 2, 1936).

3 For a personal report on some of these committees, see Romain Rolland, I Will Not Rest, trans. K. S. Shelvankar (New York, 1934), pp. 58-59, 29 1-3 17.

4 The former had been founded by Münzenberg in 1927 and included Albert Einstein, Madame Sun Yat Sen, George Lansbury, Edo Fimmen, Nehru, and Roger Baldwin in its executive. The latter, with an equally impressive list of sponsors, had been launched by a congress in Amsterdam in 1932. 
arranged by Münzenberg was the Congress for the Defense of Culture held in Paris in June, 1935, which was the largest gathering of antifascist intellectuals convened before the war. André Gide opened the congress by declaring his belief in communism before the thousands who thronged into the enormous assembly hall of the Mutualité. The ten public meetings of the congress were chaired by Waldo Frank, Heinrich Mann, Henri Barbusse, E. M. Forster, Martin Andersen-Nexö, Carlo Sforza, André Malraux, Alexei Tolstoy, and André Chamson. ${ }^{1}$ The participants constituted a veritable Who's Who of international arts and letters. Among those present were: Robert Musil, Alfred Döblin, Bert Brecht, Ernst Bloch, Lion Feuchtwanger, Ernst Toller, Anna Seghers, Max Brod, Erich Remarque, Annette Kolb, Georg Grosz, Julien Benda, Aldous Huxley, John Strachey, Karl Capek, and Ilya Ehrenburg. ${ }^{2}$

When Ernst Thälmann, the pedestrian leader of the KPD during the last years of the Weimar Republic, was imprisoned by the Nazis, Münzenberg elevated him into a symbol of the international antifascist movement. ${ }^{3}$ In March, 1934, Münzenberg launched a campaign to free "the martyred hero of the cause" with an appeal in the New York Daily Worker in which he praised Thälmann as an "honest and steadfast son of the proletariat" and called for a demonstration of millions of workers in their shops against his possible summary execution. ${ }^{4}$ In the previous month Lord Marley had been sent as an advance guard on a twentyday speaking tour of the United States to publicize Thälmann's plight and raise money for the Committee for the Relief of Victims of German Fascism. ${ }^{5}$ In May, American intellectuals and German refugees, among them Waldo Frank, Granville Hicks, Genevieve Taggard, and Alfons Goldschmidt, stepped up the campaign and by June the Worker was featuring daily protests by Dimitrov, Barbusse, Clarence Darrow, Sinclair Lewis, and Arthur Garfield Hays among others. As the capstone of this propaganda effort

\footnotetext{
1 The topics included: our cultural inheritance; humanism; the individual; the role of the writer in society; the nation and culture; and creativity and the value of intellect. See "Internationaler Schriftsteller-Kongress", in: Das neue Tage-Buch, III (June 22, 1935), p. 600 .

2 Jürgen Rühle, Literatur und Revolution (Cologne, r960), pp. 507-08. Gustav Regler recounts that at the congress there was a spontaneous feeling of solidarity and commitment among those present, which disturbed the managers of the affair who were concerned with establishing its political neutrality. Das Ohr des Malchus (Cologne, I958), pp. 314-16.

${ }^{3}$ Münzenberg, "Für Ernst Thälmann, das heisst: Gegen Faschismus, gegen imperialistischen Krieg, für den Frieden!", in: AIZ, XIII (July 26, 1934), p. 466.

4 "Make the Ernst Thälmann Trial Another Defeat for Hitler!", in: Daily Worker, XI (Mar. I 7, 1934), p. 5.

5 "Only Mass Protest Will Save Thälmann, Says Marley", Ibid., XI (Feb. 8, 1934), pp. I, 3.
} 
Münzenberg organized a fund raising and speaking tour of the United States in which he, Aneurin Bevan, and Kurt Rosenfeld, former SPD Minister of Justice in Prussia, took part. ${ }^{1}$ Münzenberg added a dramatic urgency to his appeal by announcing upon his arrival in New York that he had just received news from Germany about the impending secret trial of Thälmann and Torgler before the People's Court. ${ }^{2}$ At the end of the tour Münzenberg was feted at a banquet in New York. Once again he exhorted the audience to use every means in exerting international pressure to free Thälmann, Ludwig Renn, Carl von Ossietzky, and the thousands of other anti-fascists languishing in Hitler's jails and concentration camps. ${ }^{3}$ Propaganda on behalf of Thälmann continued in the following year and culminated in an international Thälmann Day held in Strassburg in June, $1935 .{ }^{4}$

Münzenberg performed wonders in harnessing individuals and groups of widely differing political complexions to his tangible humanitarian causes. He shunned the limelight, for he understood that the success of his enterprises often depended on their apparent spontaneity. From the moment he set foot in France in 1933, Münzenberg followed a united front policy in his activities at variance with that accepted within the communist movement. ${ }^{5}$ In effect his policy was nothing else than the popular front idea which Dimitrov made the dictum of the Comintern at its seventh world congress in 1935 . To the dismay of KPD bureaucrats, Münzenberg had pursued a similar course long before 1933 and with it attracted large numbers of fellow travelers to

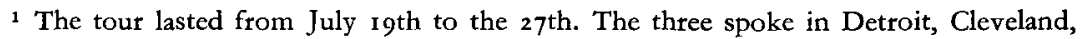
Milwaukee, and Chicago, and Bevan and Rosenfeld continued on to the West coast. Michael Foot, Aneurin Bevan (London, 1962), P. I72 and "Noted Men to Tour Country for Thälmann", in: Daily Worker, XI (July I3, I 934), p. I.

2 "Münzenberg, Appealing for Thälmann, Says Hitler Plans Mass Murder of AntiFascists", Ibid., XI (July I 9, 1934), p. 3.

s "10,000 Workers Vow Fight to Free Thälmann at Farewell Banquet to Willi Münzenbetg", Ibid., XI (July 30, I 934), p. 2.

4 An international committee under the leadership of Malraux, Gide, and Professor Paul Langevin organized this affair which was attended by delegates of national committees, scientists, doctors, lawyers, and artists. "Anti-Terrorkonferenz in Strassburg", in: Einheit, I (June, I935), p. I.

5 The Comintern's official united front from below which ushered in the "third period" in 1928 was predicated on wooing "misled" workers from their previous affiliations and established leaders. By 1934 the danger of fascism had become apparent to the men in the Kremlin and the Soviet Union concluded alliances with France and Czechoslovakia and joined the League of Nations. From the spring of that year the policy of the Comintern changed course radically in seeking united fronts from above and below which culminated in the popular front collaboration with socialist and middle-class parties. The popular front tactic came to an abrupt end with the Hitler-Stalin pact on August 23, I939. 
the cause. ${ }^{1}$ The Comintern had turned a blind eye toward his undoctrinaire methods because of his success. After 1933 he based his whole propaganda operation on the popular front both before it became and after it ceased to be Comintern policy.

It was not difficult for Münzenberg to involve uninitiated foreigners, who knew nothing about him and little about communism, in antifascist activities in which communists took an active part. More remarkable was his success in fashioning the diverse and warring factions of the German émigré left into a popular front against fascism. As early as 1933 , he attempted to win the émigré SPD rank and file for an anti-fascist united front but quickly realized that the outworn tactic of "united front from below" could have little success and abandoned it in favor of the practical popular frontism practiced in his publications and organizations. ${ }^{2}$ In 1935 he formalized what had already succeeded in practice. At the Hotel Lutetia in Paris he created a popular front committee with representatives of all important German left-wing factions. With considerable polemical skill Münzenberg argued for an anti-fascist unity between communists and social democrats or, at least, for concerted anti-fascist actions by the two groups. $^{3}$

In 1936 Münzenberg was planning a congress of the German popular front, and in preparation for the event he clarified the purpose of the organization and preached the categorical need for unity. He began by extending the olive branch to the SPD leaders in suggesting that existing differences be settled later in favor of immediate cooperation between the KPD and SPD. The SPD leaders are mistaken, however, he warned, if they believe that they will be able to return to the horse trading with financial, military, and industrial interests, which they practiced during the Weimar era, after the fall of Hitler. The people - the socialists, communists, farmers, and petty bourgeois -

${ }^{1}$ In 1925-1926 Münzenberg organized the Kuczinski-Ausschuss which arranged for co-operation between leaders of the KPD, SPD, and the trade unions in calling for a national referendum to deny former German princes compensation for their lost property. Although the left failed to carry the referendum in June 1926, it polled four million more than the combined KPD-SPD strength in the previous national election. Similarly, in February 1933 Münzenberg organized Das freie Wort, an anti-Nazi united front which included segments of the SPD and two of its leaders, Friedrich Stampfer and Toni Sender. Gross, pp. 523, 525.

2 Münzenberg, "Herr Wels verbrennt die Fahnen der II. Internationale", in: Unsere Zeit, VI (Apr. I5, I933), p. 36.

3 "Eine Frage an sozialdemokratische Freunde", in: AIZ, XV (June 3, 1936), pp. 354-55, and "I936 - Jahr der deutschen Volksfront", Ibid., XV (Jan. 30, 1936), p. 70. See also Heinrich Mann's reminiscences about the Volksfront committee of which he was the chairman. Ein Zeitalter wird Besichtigt (Stockholm, 1948), pp. 41 8-28. 
he insisted, will want a government composed of an anti-fascist coalition, which will make fundamental economic and social changes and, for a short time after the destruction of fascism, will exercise a far-reaching dictatorship. ${ }^{1}$ With practical goals always before him, Münzenberg turned from this interlude of sermonizing to the issues at hand. "Today we are not concerned with the stabilization of a bourgeois republic or with the direct creation of a soviet Germany but with overthrowing the Hitler government, the most brutal and reactionary fascist dictatorship which indiscriminately enslaves and oppresses socialist and communist workers, farmers, and bourgeois." (p. 35)

In April 1937 Münzenberg convened the congress of the German popular front in Paris. Among the three-hundred who participated, there were distinguished representatives of the SPD, the KPD, the Socialist Workers' party (SAP), and the unaffiliated left. The congress addressed an appeal to the German people exhorting it to unite against the Nazi dictatorship and ending with the slogan "freedom, peace, and bread". ${ }^{2}$ Although the spirit of co-operation prevailed at the congress, Ulbricht intrigued against it behind the scenes. He attempted to incite the various factions against each other and to establish the primacy of the KPD. ${ }^{3}$ With an obvious reference to Ulbricht and the KPD Central Committee Münzenberg warned against sectarianism. "Individual groups of the German popular front confuse it with their own organization and attempt to make the program of their organization the program of the popular front... The German popular front must fight for the concrete goal of a democratic people's republic or it will remain on the sidelines without influence on historical developments."4 The only realistic alternative to fascism in Germany, he maintained, was a democratic people's republic, and he invoked Lenin in proclaiming that there was no conflict between fighting for a democracy and for socialism. The primary goal of the popular front was to overthrow Hitler before he could unleash a world war (pp. I7, 22).

This congress proved to be the high water mark and, at the same

\footnotetext{
1 "I936 - das Jahr der Schaffung der deutschen Volksfront", in: Eine Aufgabe, pp. 34, 36-37.

2 Signatories of the appeal included: Rudolf Breitscheid, Albert Grzesinski, Professor Siegfried Marck, Alfred Braunthal, and Dr. Otto Friedlander of the SPD; Wilhelm Pieck, Walter Ulbricht, Franz Dahlem, Paul Merker, and Willi Münzenberg of the KPD; Willi Brandt, H. Diesel, and K. Franz of the SAP; and Arnold Zweig, Heinrich Mann, Professor Georg Bernhard, Rudolf Olden, Ernst Bloch, Klaus Mann, and Otto Lehmann-Russbüldt of the unaffiliated left. "Für Frieden, Freiheit und Brot", in: Rundschau über Politik, Wirtschaft und Arbeiterbewegung, VI (Jan. 14, 1937), pp. 46-47.

${ }^{3}$ Kersten, pp. 490-9I.

4 Aufgaben einer deutschen Volksfront (Paris, 1937), p. 18.
} 
time, oddly enough, the virtual end of the German popular front. Münzenberg's estrangement from the Comintern dates from this time, and in the hands of the KPD and Comintern officials, who took over his propaganda network, anti-fascism became a matter of tactics. Without Münzenberg, anti-fascist efforts such as the German popular front became thinly disguised communist instruments distrusted and eventually shunned by the sympathetic followers he had gathered and organized. ${ }^{1}$

From 1933 to 1936 the "higher authorities" left Münzenberg in peace to exercise his inventiveness in giving communist propaganda a new look. The hard men of the exiled KPD, Ulbricht and Pieck, were troublesome and generally working at cross purposes to him, but he could make light of their enmity and expose their intrigues because he was responsible to Moscow. ${ }^{2}$ The adoption of the popular front tactic by the seventh world congress of the Comintern legitimized his activities during the previous three years and made him the foremost practitioner of the new international line. When the Spanish Civil War broke out in July, I936 influential loyalists petitioned Münzenberg for assistance in their struggle. ${ }^{3}$ To him this was the long hoped for confrontation between fascism and its opponents, and he quickly became the promoter of sympathy and aid for the beleaguered republic. ${ }^{4}$ In the midst of this activity he was forced to leave for Moscow to discuss with Manuilsky the possibility of becoming head of agitprop for the Comintern. Münzenberg was unprepared to leave in the midst of the Spanish campaign, but a directive from the Comintern's executive (ECCI) could not be disobeyed.

1 Alfred Kantorowicz recounts how Ulbricht destroyed the German popular front organizations in 1937 and thereafter undermined all attempts at co-operation which were not under his direction and control. Deutsche Tagebuch (Munich, I959), Vol. II, pp. 48, 62. For the KPD's attempts to take over the German Volksfront in 1937 and the efforts of Heinrich Mann and others to prevent it, see Der Briefwechsel der nicht kommunistischen Parteien und Gruppen der deutschen Volksfront mit dem ZK der KPD, Oct., I937, Hertz archive, IISG, Amsterdam.

2 According to Kersten (loc. cit.), Ulbricht and Pieck were intent on assuming uncontested control of the KPD. As a leading German communist, with a large international following and important connections among communists and non-communists, Münzenberg was an obstacle in their quest for hegemony over the party. They attempted to undermine Münzenberg's popular front activities by taking an uncompromising line on co-operation with non-communists, and by complaining to the Comintern about his unwillingness to subordinate himself to them.

3 Buber-Neumann, p. 452.

4 Babette Gross, Münzenberg's wife, reports that in the summer of 1936 almost everyone in Paris was indifferent to the events in Spain, and she recounts her and Münzenberg's attempts to organize Spanish relief. Letter to Paulette Brupbacher, July 23, 1936, Brupbacher archive, IISG, Amsterdam. 
Upon his arrival he found the political climate to be decidedly unhealthy, for the first show trial had just concluded with the death sentence of the sixteen who allegedly comprised the "TrotskyistZinovievist Terrorist Center". He was called before the International Control Commission (ICC) of the Comintern and interrogated about the lack of security and general laxness in his Paris enterprises. He was repeatedly called to account for the presence of an alleged Franco agent, a stenotypist by the name of Liane, in one of his committees. ${ }^{1}$ At first Münzenberg refused to take this line of criticism seriously, but further hearings on the same subject put him on his guard. To be sure, his Paris organizations were concerned more with creating effective propaganda than with questions of security ${ }^{2}$ but, even from the point of view of the ICC, this represented only a minor lapse in discipline. During this inquiry he was also criticized for associating with "questionable" and "suspicious" elements and for refusing to explain these connections to the Central Committee of the KPD. ${ }^{3}$ There was also truth in this more serious charge. He had made use of persons and organizations of varying political persuasions in the course of his work, and his unwillingness to subordinate himself to Ulbricht certainly was known to the Comintern.

Nothing in these charges was new; when the ICC dismissed Münzenberg with a reprimand it was for a lack of discipline which, until then, the Comintern had countenanced and tacitly approved. The hearing and reprimand signalled the end of Münzenberg's semiautonomous operations. There is no doubt that he realized this, for his former superiors and protectors in the Comintern, Jacob MirovAbramov, head of OMS, and Ossip Piatnitzky, head of the Orgbureau, had disappeared with the first show trial. ${ }^{4} \mathrm{~A}$ further proof of the gravity of Münzenberg's position was that the ECCI no longer asked but ordered him to remain in Moscow to take over the agitprop division. He persuaded Manuilsky to let him complete his work for the Spanish Loyalists in Paris before taking on his new assignment.

\footnotetext{
1 Buber-Neumann, p. 453.

2 "The atmosphere in the Münzenberg Trust", Koestler recalls (p. 2I 2), "was more liberal and easygoing than in an orthodox party office, and one need not be afraid that an uncautious remark would be held against one on the day of reckoning." See also, Regler, p. 215 .

3 These charges were later repeated in Münzenberg's expulsion hearings before the ICC "Der Beschluss der IKK im Fall Münzenberg", in: Rundschau, VIII (Apr. I3, 1939), p. 639 .

4 Nollau, pp. 199, 2 Io. The International Relations Section (OMS) of the Comintern, to which Münzenberg was responsible, was subordinate to the ECCI's Org-Bureau. It seems that the OMS was dissolved at this time and that its functions were taken over by the territorial sections of the ECCI.
} 
In spite of this agreement, he was able to make his departure from Moscow only with the greatest difficulties. ${ }^{1}$

Upon his return to Paris Münzenberg's energies were spent. ${ }^{2}$ Early in 1937 he was forced to surrender his authority in his propaganda enterprises to Bohumil Smeral, a loyal functionary of the Comintern and member of its powerful ICC. That year was an interregnum in Münzenberg's career. For the first time in almost twenty years of communist activity he found himself at loose ends. The greatest propaganda chief the communist movement had produced suddenly was robbed of his raison d'être. The man of action, who buried himself in his work, was forced to review his activities and to take stock of his loyalties and beliefs.

Münzenberg's usefulness to the Comintern in Paris had come to an end, and there was no longer a good reason why he should not keep his promise to return to Moscow to assume leadership of agitprop. Yet, he refused to go. We can surmise that his visit the previous year had alerted him to the dangers that would await him upon his return. Most of his career in the communist movement had been spent in the service of the Comintern but always with a considerable degree of independence. He suddenly had been deprived of his favored status and was expected to abide by the rigid discipline of the Comintern headquarters in the narrow milieu of Moscow officialdom from which his friends and protectors of the Zimmerwald Left had been and were being removed. Moreover, his contacts and propagandistic successes had been in the West, and he may well have feared that as head of agitprop in Moscow he would be isolated and immobilized. Louis Fischer, a free-lance journalist and friend of Münzenberg at the time, reports that Münzenberg often spoke about his orders to return, but that he feared reprisals and was alarmed by the fate of Bukharin and other victims of the purge. ${ }^{3}$ He remained in Paris, cut off from his former activities and associates. His isolation was largely the result of intrigues by Ulbricht and Pieck. They did not attack him openly so long as there was a possibility of his return to Moscow and because he was still an important personality in émigré circles. Instead, they spread rumors about his unreliability and official disfavor and expelled

1 Only through the intercession of Palmiro Togliatti was Münzenberg able to receive his passport and exit permit. Kersten, p. 490 and Buber-Neumann, pp. 454-55.

${ }^{2}$ Immediately upon his return Münzenberg spent some time at a sanitarium in a suburb of Paris. Ibid., p. 455.

3 Interview with Louis Fischer, Princeton, New Jersey, December 19, 1963. 
some of his loyal friends and followers from the party. ${ }^{1}$ By the end of 1937 he had in fact, if not officially, become a pariah in the KPD and the Comintern.

One might well ask why this sudden fall from grace had come about. Münzenberg had been instrumental in making anti-fascism an international cause and thereby had won many new sympathizers for communism and the Soviet Union. His methods had been unorthodox - his popular frontism premature, and his fraternization with social democrats and other non-communists may have gone beyond the point of expediency - but they had brought results and were no different from those he had always employed. He had not stepped out of line; it was the communist environment which had changed. In exile he had refused to take seriously Ulbricht's unbridled struggle for control over the KPD. ${ }^{2}$ He relied on his powerful connections in the Comintern and on his indispensability as a propagandist to shield him from the intrigues of his enemies.

Münzenberg was wrong about his powerful protectors and the harmlesness of his enemies. The climate in the Soviet Union had taken a turn for the worse. The old guard of Bolshevism had been decimated in Stalin's ascent to power, and the humiliation of Zinoviev, Kamenev, Radek, Piatakov, Tukhachevsky, Tomsky, and Bukharin took in its wake the loyal cadres of the revolution who had long been the model for communists in the West. In this atmosphere of "bell, book, and candle", years of loyalty meant nothing. Men like Münzenberg, who in the line of duty had toyed with the two-edged sword of orthodoxy and heresy, were no longer trusted, and crafty plotters such as Ulbricht, who in their quest for power had always been more than pure, could deliver them the coup de grace.

It is beyond the competence of the historian to ascertain fully the moral and psychological crisis of a man who suddenly acknowledges

\footnotetext{
${ }^{1}$ Kersten, p. 492. See, for instance, a left-handed attack on Münzenberg's publishing activities in the official KPD press: "Propaganda als Waffe zum Selbstmord", in: Deutsche Volkszeitung, II (Dec. 12, I937), p. 3.

2 In 1937 it was understood among German exiles that Münzenberg had not been removed from power "because he did not abide by the popular front line decisively enough" as the KPD's whisper campaign would have it. It was apparent that he had been a major obstacle in Ulbricht's quest for power. "Das Gesetz der Selbstentmannung: Wie die KPD sich selbst liquidiert", in: Freies Deutschland, I (Aug. 5, 1937), p. 5. Babette Gross recalls that the so-called Brussels Conference of the KPD in Moscow in October I935 was preceded by a week's infighting over Thälmann's successor. Ulbricht and Pieck emerged victorious and immediately were supported by Dahlem, Ackermann, Merker, Funk, Mewis, Dengel, and others. Münzenberg, whose responsibility was to Moscow, remained an important exception to Ulbricht's and Pieck's absolute control of party affairs.
} 
his disillusionment in the purpose to which he has dedicated his life and who suddenly faces the fate of an outcast. It is surprising that Münzenberg's disillusionment did not lead to the combination of psychic collapse and desire for revenge which characterized the reaction of so many others who shared his fate. Anti-fascism played a compelling role in Münzenberg's career since his exile, and anti-fascism, it seems gave him the strength to go on after 1937 . Since 1933 it was the single cause to which Münzenberg devoted all his energies. The inquisitors of the KPD and the Comintern were theoretically right in questioning his loyalty, for he had transferted it from communism to anti-fascism which in the official view was only a weapon in a far larger struggle. Letters which he is reputed to have written to Stalin and Dimitrov would indicate that until 1938 he was unable, in spite of his understanding of Soviet realities, to sever completely his connections with the Comintern. ${ }^{1}$ It appears that he still had the need to carry on a dialogue with it and to make believe that it was a court of appeal before which he could affirm his devotion to the cause: he explained his errors as a product of his temperament, he affirmed his support of the International on larger political issues, and he upheld his methods of implementing the popular front and anti-fascism over those of the Ulbricht group.

In 1937 Münzenberg was still unable to follow his disillusionment to its ultimate conclusion. The danger of fascism was greater than ever: Hitler's power and prestige had grown, and in Spain fascism faced its first test of strength. The Comintern, he may well have reasoned, was the most committed opponent of fascism and must not be undermined by open disavowals in spite of the disastrous consequences of the purges. Münzenberg surmounted his moral and psychological crisis by organizing another propaganda network against fascism but this time as an independent impresario. It is remarkable that he succeeded without the financial and organizational assistance of the Comintern. Among orthodox communists he was an outcast, but among the countless fellow travelers, whom he had won for the cause and who were not subject to any party discipline, he was still the masterful organizer and inspiring anti-fascist. ${ }^{2}$ With their aid he brought a new propaganda organization into being.

1 The letters are reprinted in Nollau, pp. $345-46$, but the source is not indicated. Nollau informs me that copies of these letters are in an official archive in France closed to the public and, by prior agreement, kept secret by its users. Even if the letters are authentic their servile tone (and here Nollau agrees) does not represent Münzenberg's true feelings toward the Comintern. Letter to me from Günther Nollau, Apr, 23, 1964 .

2 The Swedish banker Olof Aschberg, for instance, who was a stanch supporter of the Soviet Union, did not abandon Münzenberg during this critical period. Buber-Neumann, p. 456 . 
The signal for the start of Münzenberg's independent operation was his publication of an article and a book on propaganda as an ideological weapon. ${ }^{1}$ These publications were devoted to a careful analysis of the methods by which Hitler made German propaganda an effective means in the "cold war" with the West and the Soviet Union. Hitler, he maintained, used propaganda as a form of psychological warfare against the German masses which he had learned to control like a herd of sheep and operated the most technically developed and widespread propaganda apparatus in the world with the effectiveness of a secret weapon. Münzenberg exhorted his readers to take heed, to organize a unified counter-propaganda that would take the offensive against fascism, and, by making known the truth, would unmask the falsehoods and expose the aggressive intentions of the enemy.

In the summer of 1937 Münzenberg joined the Deutsche Freibeitspartei, which was to pursue a popular front policy in combating fascism and in laying the plans for a reconstructed Germany. ${ }^{2}$ The center of Münzenberg's new propaganda network was the publishing house Editions Sebastian Brant which issued books by René Schickele, Emil Ludwig, Rudolf Leonhard, Kurt Kersten, and others. It also published the military-political review Krieg und Frieden edited by the former Austrian Secretary of State for military affairs Julius Deutsch. Among its collaborators were: Pierre Cot, French Air Minister, Major C. R. Attlee, Michael Karolyi, Münzenberg, Pietro Nenni, Fritz Sternberg, Max Werner, Kurt Kersten, and Paul Frölich. Münzenberg's most important publication was Die Zukunft, a weekly with an expensive format and impressive list of contributors. They included members of the German literary emigration such as Alfred Döblin, Arnold Zweig, Thomas and Heinrich Mann, Franz Werfel, Ernst Toller, and Lion Feuchtwanger; foreign writers such as Ignazio Silone, Aldous Huxley, François Mauriac, G.P.Gooch, H.G. Wells, Julien Benda, and Kingsley Martin; and foreign political figures such as Leon Jouhaux, Pietro Nenni, Francesco Nitti, Carlo Sforza, C.R. Attlee, Georges Bidault, Jawaharlal Nehru, Norman Angell, and Harold MacMillan.

The political complexion of the contributors to Die Zukunft serves

\footnotetext{
1 "Propaganda als Waffe", in: Die neue Weltbühne, XXXIII (May I3, 1937), pp. 623-26 and Propaganda als Waffe (Paris, 1937).

2 The Deutsche Freiheitspartei was founded in the beginning of 1937 by Otto Klepper, last Finance Minister of Prussia. It sought to aid the forces offering resistance to Nazism in Germany and published the Freiheitsbriefe addressed to the "democratic forces of Germany" and smuggled into the country by the hundred thousands. Gross, p. 539. By the fall of 1937 , the organization held a meeting in Dijon at which Heinrich Mann was one of the main speakers. Kersten, pp. 491-92.
} 
as a valuable index to the political orientation of Münzenberg's last propaganda enterprise. There were still a large number of left-wing sympathizers, but instead of the contingent of communists one might have found before 1937 , there were now a sizable number of representatives of a middle-of-the-road position. This shift in political focus can in part be explained as an expression of necessity resulting from Münzenberg's isolation from the communist movement. More important in producing this political orientation may have been his growing conviction that the increasing threat of fascism in 1938 and I 939 could not be checked by a narrow sectarianism. By including more and more non-leftists in his enterprises he may have hoped to move closer to the locus of power in some of the Western democracies. At the same time he moved further away from communism, for he no longer drew a distinction between an alliance with the bourgeoisie during a crisis and what, as a communist, he should have recognized as "class collaboration." Ideologically he was adrift and his demands for "democratic socialism" as an antidote to Stalinism were vague formulations. Münzenberg did not realize that he, the great proselytizer of fellow travelers, had become his own most illustrious convert.

This tendency toward a wider-based popular front against fascism was also apparent in the new organizations which Münzenberg called into being in 1938 and 1939. He organized the committee Menschen in Not to aid all persecuted Germans $;^{1}$ the Deutsch-Ausschuss composed of Austrian and German social democrats, members of the Sozialistiscbe Konzentration, and ex-communists, with the purpose of drafting a democratic socialist platform; the Auslandskomitee der Freunde der sozialistischen Einheit Deutschlands composed of former communist Reichstag deputies who favored a broad popular front; and a committee to aid the neglected Spanish refugees interned at Gurs in Southern France. Münzenberg's organizations also established contact with Lord Robert Cecil's influential international pacifist organization Rassemblement Universel de Paix and campaigned on its behalf. ${ }^{2}$

The most significant of these undertakings was L'Union FrancoAllemande. Its president was Edouard Herriot, and its large membership included Julien Benda, Georges Bidault, Pierre Cot, George Duhamel, and important members of the Chamber of Deputies, professors, and officials of the CGT, as well as Thomas Mann, Otto Klepper, Hermann Rauschning, Alvin Kronacher, Alfred Döblin,

1 This committee aided, among others, German refugees interned in France after the outbreak of war. It distributed food and clothing parcels to the German inmates of the camps including the communists who had reviled and blacklisted Münzenberg.

2 Comment empêcher l'agression hitlérienne? Memoire des amis Allemands de la Paix sur la Politique de Guerre de Hitler et la Volonté de Paix du Peuple Allemand (Paris, 1938). 
E. J. Gumbel, Arthur Koestler, and other leading German refugees. ${ }^{1}$ Münzenberg also created an English counterpart to the Union which went under the name of The Federal Fellowship, numbered Norman Angell, John Parker, the Earl of Listowel, H.G. Wells, and Storm Jameson among its members, and published a periodical, ToMorrow. ${ }^{2}$ In all of his organizational activities Münzenberg was more intent than ever on uniting the various factions of the German émigré left. He considered the former differences between communists and social democrats out of date. ${ }^{3}$ He failed to gain the confidence of the SPD leadership in Prague but succeeded in winning the trust of Breitscheid and Hilferding.

Münzenberg's popular frontism, in which communists played a negligible role, and his attacks on Stalin's policies in Spain finally forced the hand of the KPD and the Comintern. ${ }^{4}$ In March of 1939 the KPD began to enumerate Münzenberg's crimes. He was accused of opportunism - of being all things to all men - in his endeavors for a German popular front; of obstructing "true" popular frontism by throwing suspicion on the motives of the KPD; of betraying his own party through his association with social democratic groups; and, ultimately, of being "a parasite of the working class". ${ }^{5}$ The party press in April reported Münzenberg's expulsion from the KPD based on the hearing held by the ICC of the Comintern on January 2oth and February I6th. The ICC traced his "deviations" back to his opposition to Thälmann and the "social fascist" line of I93 I and 1932. It found him guilty of having intrigued against the KPD during all the years of his exile. He allegedly conspired with Trotskyists and other enemies of the proletariat; maligned the KPD leadership and discredited it before non-communist elements; and refused to submit his propagan-

1 The purpose of the organization, which was announced in a special edition of Die Zukunft, II (Apr. 28, 1938), p. I, was to further the maintenance of peace and to promote harmonious relations between France and a reconstructed Germany of the future.

2 "Eine englisch-deutsche Union", Ibid., II (July 28, x 939). From time to time the Zukunft appeared in special English editions.

3 "Zut Bündnispolitik der Atbeiterklasse", Ibid., I (Oct. I 2, 1938), pp. 6-7.

4 According to Kersten (pp. 493-94) Münzenberg's material and ideological aid to the Spanish loyalists, who streamed into the internment camp at Gurs completely disillusioned by the communist terror in Barcelona and Albacete, was a threat to communism's international image. Until August 1939 Münzenberg defended himself before the German émigré left against the KPD charges that he had allied himself with "Gestapo agents, confidence men, thieves, and German Poumists" at the camp in Gurs. Circular letter by Münzenberg: An die kommunistischen Genossen und Spanienkämpfer im Lager Gurs, Aug. 9, I939, Hertz archive, IISG, Amsterdam.

5 “Der Fall Münzenberg", in: Rundschau, VIII (Mar. 23, 1939), pp. 449-5o. 
distic activities to party discipline. ${ }^{1}$ From the point of view of KPD and Comintern orthodoxy Münzenberg was in fact guilty of some of the charges against him. He had deviated from the "correct" line by considering anti-fascism based on the popular front as an end rather than as the means toward strengthening the Soviet Union. In this heresy lay the dilemma of so many non-Russian communists who, during this period, were torn between loyalty to some national or international cause and obedience to the authority of the Soviet Union.

The signing of the Hitler-Stalin pact on August 23 rd was the turning point in the lives of many loyal communists. This was particularly true of those who had devoted their lives to anti-fascism. It would be a half-truth to say that Münzenberg was shattered by the event, for his estrangement from the movement had begun earlier and was accelerated in the years after his return from Moscow. The HitlerStalin pact merely made it possible for him to take the final step of disengagement from a cause in whose Russian spokesmen he had long ago lost confidence.

For Münzenberg August 23 rd marked the end of equivocation, and he lost little time in appraising the significance of the pact. He accused the Soviet Union of having betrayed the cause of peace. ${ }^{2}$ National Socialism, he announced, would remain the main enemy of the German people and of Europe regardless of who became its ally. Stalin is gambling on Hitler, and he will lose; the German opposition is gambling on the liberal forces of Europe, and it will win. The Western powers, he continued, are the beleaguered fortress of the democratic and socialist forces of the world, and, even if they have a conservative leadership, the cause of German freedom is in their camp. ${ }^{3}$

Münzenberg carefully detailed his rejection and condemnation of the pact: it led to an increase of international tension; it accelerated preparations for war; it was not a non-aggression pact but one of mutual aid involving the mortal enemy of socialism; it nullified Stalin's promise to protect the independence of small nations under all circumstances; it had been carried out by secret diplomacy formerly

1 "Der Beschluss der IKK im Fall Münzenberg" and "Ausschluss Münzenbergs aus der KPD", Ibid., VTII (Apr. I3, 1939), pp. 639-40. The character assassination of Münzenberg was answered in a statement by the former KPD Reichstag deputies Peter Maslowski, Walter Oettinghaus, and Grete Hahne, signed by seventy-four KPD members many of whom were Spanish Civil War veterans. After recounting Münzenberg's career as founder and champion of communism, it accused the KPD of historical falsification and of speaking about decency, human rights, and democracy while denying the same to its own members. Circular letter: Wer die Wahrheit kennt und sie nicht spricht, der ist fürwahr ein feiger Wicht, Aug. 20, 1939, Hertz archive, IISG, Amsterdam.

2 "Klare Fronten", in: Zukunft, II (Aug. 28, 1939), p. 3.

3 "Der Hitler-Stalin Pakt und die Westmächte", Ibid., II (Aug. 28, 1939), p. 5. 
condemned by the USSR; it strengthened the anti-Soviet coalition in all countries, which was formerly held in check by the sympathy of the masses for the Soviet Union; and it marked the betrayal by leaders of the Comintern of its members. ${ }^{1}$

Münzenberg had often enough bent principle to serve the exigency of the moment, but he regarded the pact as a compromise of kind rather than degree. With it the Soviet Union had descended to the level of Realpolitik, given the lie to its ideological formulations and appeals, and besmirched those who had served it out of a belief in its ideals. The pact, Münzenberg observed, was nothing less than a Russian "stab in the back" against the working class and peace. "For years a controlled press has agitated and slandered, has spread hundreds of vile lies and suspected thousands of brave workers. No issue of the Volkszeitung [official KPD newspaper] appeared without repeating a thousand times: 'Down with the vermin; down with the traitor.' Today, millions are arising in every country; they point to the East and shout: 'You, Stalin, are the traitor."' Although Stalin was the main object of Münzenberg's polemics, Ulbricht, Pieck, and Dahlem were also subjected to a fierce attack. Why, Münzenberg asked sarcastically, were these champions, who had previously threatened to crush Hitler with Soviet might so singularly silent now? Had they met the fate of Neumann, Remmele, and Flieg ? ${ }^{3}$ Ulbricht's long awaited reaction to the pact and the war was a masterpiece of casuistry. In a formulation reminiscent of the conservative ideologue Arthur Moeller van den Bruck he branded Britain as the capitalistic-imperialistic warmonger. The German workers, he insisted, have no intention of overthrowing their present regime on behalf of capitalism in Germany, Britain, France, or elsewhere. All those, he added, who intrigue against the friendship of the German and Soviet peoples are an enemy of the German people and abettors of British imperialism. ${ }^{4}$

\footnotetext{
1 "In der Freiheitsfront für die Einheitspartei", Ibid., II (Aug. 28, 1939), pp. 6-7. Shortly after the outbreak of the war Münzenberg branded the KPD as the party which had betrayed the German people in their most difficult hour and demanded that it be destroyed along with Hitler. In a liberated Germany, he prophesied, there would be no room for dictators regardless of their persuasion. "Das muss verhindert werden", Ibid., II (Sept. 6, I939), p. 4. In a similar vein, see the two editorials "Die deutsche Freiheit im Kampf gegen Hitler und Stalin" and "Her zu uns! Offener Brief an Freunde in Deutschland und im Ausland!", Ibid., II (Sept. 22, I939), p. I.

2 "Der russische Dolchstoss", Ibid., II (Sept. 22, 1939), p. I.

3 "Die deutschen Kommunisten in Moskau verboten", Ibid., III (Oct. 27, 1939), p. 3. See also "Eine Front: die deutschen Kommunisten verstärken ihre Hitlerpropaganda", Ibid., III (Jan. 26, 1940), p. I. In 1937 the leading German communists Heinz Neumann, Hermann Remmele, and Leo Flieg disappeared mysteriously in Moscow.

4 "Hilferding über den 'Sinn des Krieges", in: Die Welt: Zeitschrift für Politik, Wirtschaft und Arbeiterbewegung, No. 6 (Feb. 9, 1940), pp. 135-37.
} 
With the outbreak of the war Münzenberg was more isolated than ever. ${ }^{1}$ Most of the German refugees in France were sent to internment camps, and his foreign associates abandoned propaganda for direct action against fascism. Almost singlehandedly he published Die $Z u$ kunft until May 1940 but its editorial fire was drawn. Pessimism alternated with calls for democratic socialism, and the former impresario was forced to recognize that he was the object of forces beyond his control. ${ }^{2}$ During the German offensive in May I940 Münzenberg was interned and assigned to a work company attached to a French regiment near Lyon. Early in June the regiment fled toward Valence in order to cross the Rhone and thereby escape the rapidly advancing German armies. During this forced march discipline disintegrated and soldiers and internees found individual means of speeding to safety. Münzenberg was last seen on June 2 Ist when he left his companions to search for an auto which would take him to Gurs where his wife was interned. His death was reported fout months later; it remains unexplained. ${ }^{3}$

It would be all too easy to characterize Münzenberg's career from 1933 to 1940 as an example of the road to reformism and anticommunism. But his alienation from Comintern communism was more than another instance of the "God that failed." Münzenberg's transformation from communist propaganda chief to popular front socialist symbolizes the deterioration of the communist movement of the twenties and thirties. Bolshevization and russification of the Comintern led ultimately to the estrangement and destruction of many of its most able non-Russian leaders. The constantly reversing theoretical and tactical policy of the Comintern left many "heretics" by the wayside, and the career of Münzenberg illustrates that the game of orthodoxy and blind obedience had to be played without reservations

\footnotetext{
${ }^{1}$ For the mutual recriminations and petty squabbling to which the émigré left had descended by 1940, see Copy of letter by Jacob [Walcher] to Münzenberg, Apr. I3, 1940; Letter by Münzenberg to Jacob [Walcher], Apr. I6, I940; and Copy of letter by Münzenberg and Oettinghaus to Paul Bernard, Apr. I9, I940, Hertz archive, IISG, Amsterdam. 2 "Ein Jahr vergeblichen Kampfes", in: Zukunft, II (Oct. I3, 1939), p. 5, and "Frieden, Freiheit, Sozialismus", Ibid., III (Dec. 15, 1939), p. I.

${ }^{3}$ Kersten (pp. 495-99) investigated the death and found that the few existing records had been destroyed by the French authorities in 1950. Kersten, quite rightly, discounts the possibility of suicide. This leaves two likely alternative explanations: murder by the Gestapo or by the NKVD. A recent journalistic account based in part on first-hand investigation underlines the mystery surrounding Münzenberg's death. See Jorgen Schleimann, "The Life and Work of Willy Münzenberg", in: Survey, No. s5 (April, i 965), pp. 86-90.
} 
or not at all. Münzenberg found that he could not abide by the turnabouts of the Russian-dominated Comintern which, instead of admitting that its tactical shifts were prompted by political expediency, endowed them with the virtues of an elasticized Marxism-Leninism.

In retrospect it appears that Münzenberg had ceased being an orthodox communist soon after he undertook the direction of the propaganda campaign in Paris. ${ }^{1}$ He had witnessed the woeful collapse of his own party under the onslaught of the Nazis, and as a German communist feared the danger of fascism to the movement and the civilized world much more than did the functionaries of the Comintern. He welcomed the tactic of anti-fascism not only as a necessary maneuver on the part of the international movement; it also gave him the opportunity to commit himself wholly against what he believed to be the greatest evil of his time. The aims of the Comintern and Münzenberg's additional motives were both served by his propaganda efforts in Paris. Münzenberg did not realize at the time that he was elevating a mere tactic into a goal and thereby substituting anti-fascism for communism which, in the eyes of the orthodox, depended on the preservation of the Soviet Union at all costs. Gradually and unconsciously he exchanged the immediate means for the ends of the movement until his own course became a matter of principle from which he could not retreat.

The large measure of independence which the Comintern allowed him in his operations contributed to his alienation from communism. He was the head of a virtual propaganda empire outside the narrow confines of his own party and responsible only to distant Moscow. In this setting he enjoyed a freedom of action which must have swelled his ego and prevented him from accepting discipline when it was finally imposed. He bridled at the sudden attempts at control, for, at his nerve center in the West, he considered himself better able to assess international conditions than the officials in Moscow. His loyalty to communism was probably also weakened by his constant association with non-communists. In the process of implementing the

1 During his activity in Germany Münzenberg at times acted contrary to the official KPD or Comintern line which, at the same time, he supported publicly. Thus, for instance, he sided with Heinz Neumann in the leadership struggle which ensued after the breakup of the Thälmann-Neumann-Remmele triumvirate in 1931 and attempted to help divert the energies of the party from a sterile attack on the SPD to a full-scale campaign against the Nazis. Erich Matthias and Rudolf Morsey (eds.), Das Ende der Parteien 1933 (Düsseldorf, I960), p. 677. This tendency periodically to observe orthodoxy in the breach was not a sign of disloyalty. Münzenberg disagreed with certain tactics of the KPD and the Comintern but never so seriously as to go into opposition. The nature of his work as propagandist made it possible for him to stretch orthodoxy but there is no evidence that before I 933 he was inclined to disavow it. 
popular front policy he may have been influenced by those whom he converted and driven further from the path of orthodoxy by the necessary compromises of his vocation. The catalyst in Münzenberg's eventual defection from the movement was the purges in which the revolutionists of his generation were reviled, defamed, and destroyed. In their fate he may have seen a foreshadowing of his own. Münzenberg's political and moral catharsis was much more important than the loss of faith of numerous part-time communists and converts, for he was a member of the old guard and an important functionary. His fate points up the failure of the communist movement to be both national and international and illustrates anew how a revolution can devour its most gifted sons. 